\title{
Availability of lysine in vegetable protein concentrates as determined by the slope-ratio assay with growing pigs and rats and by chemical techniques
}

\author{
BY E. S. BATTERHAM, R. D. MURISON AND R. F. LOWE \\ NSW Department of Agriculture, Agricultural Research Centre, Wollongbar, \\ New South Wales 2480, Australia
}

\section{(Received 12 August 1980 - Accepted 29 September 1980)}

1. The availability of lysine in seven vegetable protein concentrates was determined using the slope-ratio assay with growing pigs and rats and with two chemical techniques.

2. With pigs, estimates of availability were lower using carcass compared to live-weight values, but there was no consistent effect of including food intake in the criterion of response. Availability estimates, using food conversion efficiency on a carcass basis were (proportion of total) linseed meal -0.23 , lupin-seed meal 0.74 , rapeseed meal no. 10.97 , no. 20.77 , sunflower meal no. 10.59 , no. $20 \cdot 66$, no. $30 \cdot 54$.

3. Availability estimates for lysine with rats were also lower using carcass compared to live-weight values. Estimates based on food conversion efficiency were higher than those based on weight gain. Availability estimates in lupin-seed meal and sunflower meals were in general agreement with the pig estimates, whilst that with linseed meal was considerably higher (0.82). Assays were not conducted with rapeseed meal due to problems of food rejection with this meal.

4. The differences in available lysine were not detected by the chemical Silcock available-lysine test (Roach $e t$ al. 1967) nor by the direct fluoro-dinitrobenzene procedure (Carpenter, 1960).

Batterham et al. (1979) reported the development of a slope-ratio assay for available lysine in protein concentrates with growing pigs. Availability estimates using this assay indicated substantial differences in the availability of lysine in cottonseed meal $(0.43)$ and meatand-bone meal $(0.49)$ compared to fish meal $(0 \cdot 89)$, skim-milk powder $(0.85)$ and soya-bean meal $(0 \cdot 84)$. These differences were also detected by slope-ratio assays with rats but not by the chemical Silcock available-lysine assay (Roach et al. 1967) nor by the direct fluorodinitrobenzene (FDNB) available-lysine test (Carpenter, 1960).

This paper reports the determination of available lysine in a series of vegetable protein concentrates using the slope-ratio assay with pigs and rats. The protein concentrates were also analysed with the Silcock (Roach et al. 1967) and direct FDNB (Carpenter, 1960) available-lysine assays to determine if these techniques were applicable in these meals. Previous work (Batterham et al. 1979) had also indicated that slope-ratio values based on carcass values were more applicable with pigs than those based on live-weight values; this aspect was also examined for slope-ratio assays with rats.

\section{EXPERIMENTAL}

\section{Protein concentrates}

The chemical composition of the seven vegetable protein concentrates is presented in Table 1. All meals were 'prepress' solvent-extracted except lupin-seed meal (raw seed, coarsely crushed with a hammer mill) and sunflower meal no. 2 (expeller processed).

Pig slope-ratio assays

Two meals (rapeseed meal no. 1 and sunflower meal no. 1) were assayed in Expt 1 and the remaining five in Expt 2.

Expt 1. For this assay, the two protein concentrates were assayed in the one experiment. 
This involved the use of thirteen diets; the basal diet (blanks), four diets to determine the pig's response to standard lysine and eight for the two protein concentrates (four/protein concentrate). The basal diet contained $(\mathrm{g} / \mathrm{kg})$ : wheat 690 , wheat gluten 60 , mineral and vitamin premix 5 (composition as in Batterham et al. (1979)), bone flour 30 and starch 215. The wheat and wheat gluten were the same batch as used by Batterham et al. (1979) and supplied adequate quantities of all amino acids to allow a linear response to the added free lysine.

The four levels of lysine used to determine the pig's response to standard lysine were in $750 \mathrm{mg}$ increments of L-lysine $/ \mathrm{kg}$ and were obtained by the addition to the basal diet of L-lysine monohydrochloride, anhydrous, $98 \%$ pure, supplied by Ajinomoto Co. Inc., Japan. The protein concentrates were incorporated into the basal diets to provide four levels of total lysine, again in $750 \mathrm{mg} / \mathrm{kg}$ increments, at the expense of wheat starch. Dietary energy was maintained at $14.5 \mathrm{MJ}$ digestible energy $/ \mathrm{kg}$ diet using wheat starch and tallow as non-protein energy sources.

The thirteen diets were arranged in a randomized block design with four pigs allocated to each diet. Two pigs were females and two were males, all of the Large White breed. The pigs were penned individually and water supplied by 'nipple' drinkers. Dietary treatments were introduced when the pigs reached $20 \mathrm{~kg}$ live weight.

The diets were offered at a daily rate of $1000 \mathrm{~g}$ at $20 \mathrm{~kg}$ live weight, with $100 \mathrm{~g}$ increments $/ 2.5 \mathrm{~kg}$ live-weight gain. The pigs were fed eight times daily, at intervals of $3 \mathrm{~h}$, to ensure the utilization of the added free lysine (Batterham \& O'Neill, 1978). The food was offered dry. Rations were adjusted after the weekly weighings of the pigs.

The pigs were slaughtered after reaching a minimum weight of $45 \mathrm{~kg}$ and hot eviscerated carcass weights recorded. The ham was dissected and the lean content used as an indicator of carcass leanness. Pig response was assessed in terms of daily live-weight gain, food conversion efficiency (FCE; $\mathrm{kg}$ live-weight gain $/ \mathrm{kg}$ food eaten), dressing proportion (hot carcass weight as a proportion of live weight), lean content of the ham, carcass gain $/ \mathrm{d}$ (kg hot carcass weight $-\mathrm{kg}$ initial live weight $\times 0.69 \div$ period (d) on experiment) and FCE on a carcass basis ( $\mathrm{kg}$ hot carcass weight $-\mathrm{kg}$ initial live weight $\times 0.69 \div \mathrm{kg}$ food intake). The factor of 0.69 for estimated carcass weight was previously determined with ten piglets (five males and five females) slaughtered at $20 \mathrm{~kg}$ live weight.

Expt 2. For this assay, the five protein concentrates were assayed in the one experiment. This involved the use of thirty-two diets; the basal diet (blanks), six diets to determine the pig's response to standard lysine and twenty-five for the five protein concentrates (five/protein concentrate). The basal diet contained $(\mathrm{g} / \mathrm{kg})$ : wheat 640 , wheat gluten 60 , L-lysine monohydrochloride (anhydrous) 1.41, DL-methionine 0.30, L-threonine 0.90, mineral and vitamin premix 5 (composition as in Batterham et al. (1979)), bone flour 30, and starch 262-39. The wheat was the same as in Expt 1 but the wheat gluten was a new batch. The combination of wheat and wheat gluten supplied adequate quantities of all the amino acids except lysine, which was added to bring the basal level up to $5 \cdot 2 \mathrm{~g} / \mathrm{kg}$, and methionine and threonine, which were added to ensure adequacy according to estimates of Lewis \& Cole (1976). The six levels of lysine used to determine the pig's response to standard lysine were in $500 \mathrm{mg}$ increments of L-lysine/ $\mathrm{kg}$ (same batch as in Expt 1). The protein concentrates were incorporated into the basal diets to provide five levels of total lysine, again in $500 \mathrm{mg} / \mathrm{kg}$ increments, at the expense of wheat starch. Dietary energy was maintained at $14.5 \mathrm{MJ}$ digestible energy $/ \mathrm{kg}$ diet using wheat starch and tallow as non-protein energy sources.

The design of the experiment, allocation of animals/treatment, method of procedure and assessment of performance was as outlined for Expt 1. 
Table 2. Expt 1.* Live-weight gain, food conversion efficiency (FCE), carcass gain, FCE on a carcass basis, dressing proportion and lean content of hams of pigs during the $20-45 \mathrm{~kg}$ growth phase when fed on the diets for the slope-ratio assay for lysine

\begin{tabular}{|c|c|c|c|c|c|c|}
\hline \multirow[b]{2}{*}{$\begin{array}{l}\text { Lysine dose } \\
\text { level }(\mathrm{g} / \mathrm{kg})\end{array}$} & \multicolumn{3}{|c|}{ Live-wt gain $(g / d)$} & \multicolumn{3}{|c|}{ FCE $\dagger$} \\
\hline & $\begin{array}{c}\text { Free } \\
\text { lysine }\end{array}$ & $\begin{array}{l}\text { Rapeseed } \\
\text { meal }\end{array}$ & $\begin{array}{l}\text { Sunflower } \\
\text { meal }\end{array}$ & $\begin{array}{c}\text { Free } \\
\text { lysine }\end{array}$ & $\begin{array}{l}\text { Rapeseed } \\
\text { meal }\end{array}$ & $\begin{array}{c}\text { Sunflower } \\
\text { meal }\end{array}$ \\
\hline 0 & 331 & - & - & 0.300 & - & - \\
\hline 0.75 & 421 & 418 & 354 & 0.332 & 0.341 & 0.306 \\
\hline 1.50 & 468 & 450 & 439 & 0.355 & 0.364 & 0.347 \\
\hline $2 \cdot 25$ & 544 & 530 & 480 & 0.404 & 0.408 & 0.365 \\
\hline \multirow[t]{4}{*}{3.00} & 547 & 587 & 502 & 0.419 & 0.429 & 0.390 \\
\hline & & SEM 23 & & & SEM 0.009 & \\
\hline & \multicolumn{3}{|c|}{ Carcass gain $(\mathrm{g} / \mathrm{d})_{+}^{\ddagger}$} & \multicolumn{3}{|c|}{ FCE (carcass basis) $\|$} \\
\hline & $\begin{array}{c}\text { Free } \\
\text { lysine }\end{array}$ & $\begin{array}{c}\text { Rapeseed } \\
\text { meal }\end{array}$ & $\begin{array}{c}\text { Sunflower } \\
\text { meal }\end{array}$ & $\begin{array}{c}\text { Free } \\
\text { lysine }\end{array}$ & $\begin{array}{c}\text { Rapeseed } \\
\text { meal }\end{array}$ & $\begin{array}{c}\text { Sunflower } \\
\text { meal }\end{array}$ \\
\hline 0 & 266 & - & - & 0.243 & - & - \\
\hline 0.75 & 337 & 319 & 287 & 0.266 & 0.260 & 0.247 \\
\hline 1.50 & 367 & 357 & 345 & 0.278 & 0.289 & 0.273 \\
\hline 2.25 & 424 & 404 & 371 & 0.315 & 0.310 & 0.282 \\
\hline \multirow[t]{4}{*}{3.00} & 426 & 437 & 374 & 0.326 & 0.320 & 0.291 \\
\hline & & SEM 18 & & & SEM 0.007 & \\
\hline & \multicolumn{3}{|c|}{ Dressing proportion $\S$} & \multicolumn{3}{|c|}{ Lean in ham $(\mathrm{g} / \mathrm{kg})$} \\
\hline & $\begin{array}{c}\text { Free } \\
\text { lysine }\end{array}$ & $\begin{array}{c}\text { Rapeseed } \\
\text { meal }\end{array}$ & $\begin{array}{l}\text { Sunflower } \\
\text { meal }\end{array}$ & $\begin{array}{c}\text { Free } \\
\text { lysine }\end{array}$ & $\begin{array}{c}\text { Rapeseed } \\
\text { meal }\end{array}$ & $\begin{array}{c}\text { Sunflower } \\
\text { meal }\end{array}$ \\
\hline 0 & 0.750 & - & - & 579 & - & - \\
\hline 0.75 & 0.752 & 0.732 & 0.753 & 589 & 570 & 582 \\
\hline $1 \cdot 50$ & 0.743 & 0.748 & 0.744 & 589 & 594 & 582 \\
\hline $2 \cdot 25$ & 0.742 & 0.732 & 0.737 & 607 & 584 & 592 \\
\hline \multirow[t]{2}{*}{3.00} & 0.741 & 0.721 & 0.723 & 611 & 609 & 621 \\
\hline & & SEM 0.008 & & & SEM 29 & \\
\hline
\end{tabular}

* For details, see p. 401.

$\dagger$ Live-weight gain $(\mathbf{k g}) \div$ food intake $(\mathbf{k g})$.

$\ddagger$ Hot carcass weight - initial live weight $\times 0.69 \div$ period (d) on experiment.

\|Hot carcass weight - initial live weight $\times 0.69 \div$ food intake.

$\S$ Hot carcass weight as a proportion of live weight before slaughter.

\section{Statistical analyses}

The results for dressing proportion and lean content of the hams were regressed $v$. lysine for each protein concentrate. The results for daily live-weight gain, FCE, carcass gain/d, and FCE on a carcass basis were analysed by the slope-ratio technique of Finney (1964) for multiple assays. The availabilities and their standard deviations were calculated.

\section{Rat slope-ratio assay}

For the rat assays, single separate assays were conducted for each protein concentrate. A total of seven diets were used for each assay: the basal diet (blanks), three diets to determine the rat's response to standard lysine and three diets to determine the rat's response to the protein concentrate. The basal diet contained $(\mathrm{g} / \mathrm{kg})$ : wheat 650 , wheat gluten 100 , DL-methionine $1 \cdot 5$, $\mathrm{L}$-threonine $0 \cdot 7$, maize oil 20 , bone flour 25 , mineral and vitamin premix 5 (composition as reported by Batterham et al. (1979)) and wheat starch 197.8. The combination of wheat and gluten supplied adequate levels of all amino acids except lysine 
Table 3. Expt 2.* Live-weight gain, food conversion efficiency (FCE) and lean content of hams of pigs during the $20-45 \mathrm{~kg}$ growth phase when fed on the diets for the slope-ratio assay for lysine

\begin{tabular}{|c|c|c|c|c|c|c|}
\hline \multirow[b]{2}{*}{$\begin{array}{l}\text { Lysine dose } \\
\text { level }(\mathrm{g} / \mathrm{kg})\end{array}$} & \multicolumn{6}{|c|}{ Form of lysine addition } \\
\hline & $\begin{array}{c}\text { Free } \\
\text { lysine }\end{array}$ & $\begin{array}{c}\text { Linseed } \\
\text { meal }\end{array}$ & $\begin{array}{l}\text { Lupin-seed } \\
\text { meal }\end{array}$ & $\begin{array}{c}\text { Rapeseed } \\
\text { meal }\end{array}$ & $\begin{array}{c}\text { Sunflower } \\
\text { meal }\end{array}$ & $\begin{array}{c}\text { Sunflower } \\
\text { meal }\end{array}$ \\
\hline \multicolumn{7}{|c|}{ Live-wt gain $(g / d)$} \\
\hline 0 & 481 & - & - & - & - & - \\
\hline 0.5 & 493 & 513 & 496 & 486 & 516 & 486 \\
\hline 1.0 & 517 & 489 & 527 & 533 & 541 & 547 \\
\hline 1.5 & 546 & 527 & 563 & 542 & 543 & 538 \\
\hline $2 \cdot 0$ & 567 & 514 & 586 & 559 & 564 & 554 \\
\hline 2.5 & 572 & 494 & 596 & 563 & 585 & 588 \\
\hline $3 \cdot 0$ & 607 & - & - & - & - & - \\
\hline \multicolumn{7}{|c|}{ SEM 15} \\
\hline \multicolumn{7}{|c|}{ FCE $\dagger$} \\
\hline $\mathbf{0}$ & $0 \cdot 361$ & - & - & - & - & - \\
\hline 0.5 & $0 \cdot 370$ & 0.384 & $0 \cdot 369$ & 0.365 & 0.382 & 0.362 \\
\hline 1.0 & 0.391 & 0.380 & 0.396 & 0.396 & 0.403 & 0.408 \\
\hline 1.5 & 0.410 & 0.391 & 0.417 & 0.403 & 0.404 & 0.402 \\
\hline $2 \cdot 0$ & 0.420 & 0.387 & 0.433 & 0.419 & 0.415 & 0.411 \\
\hline $2 \cdot 5$ & 0.420 & 0.374 & 0.436 & 0.425 & 0.430 & 0.432 \\
\hline $3 \cdot 0$ & 0.454 & - & - & - & - & - \\
\hline \multicolumn{7}{|c|}{ SEM 0.009} \\
\hline \multicolumn{7}{|c|}{ Lean in ham $(\mathrm{g} / \mathrm{kg})$} \\
\hline 0 & 586 & - & - & - & - & - \\
\hline 0.5 & 612 & 598 & 608 & 612 & 590 & 612 \\
\hline 1.0 & 635 & 603 & 606 & 608 & 611 & 618 \\
\hline 1.5 & 632 & 630 & 628 & 613 & 632 & 623 \\
\hline 2.0 & 631 & 660 & 635 & 633 & 632 & 630 \\
\hline 2.5 & 650 & 633 & 645 & 633 & 646 & 644 \\
\hline 3.0 & 656 & - & - & - & - & $\ldots$ \\
\hline \multicolumn{7}{|c|}{$\operatorname{SEM} 9$} \\
\hline
\end{tabular}

- For details, see p. 403 . † Live-weight gain $(\mathrm{kg}) \div$ food intake $(\mathrm{kg})$.

$(4.7 \mathrm{mg} / \mathrm{kg})$, methionine and threonine. The latter two were added to ensure adequacy according to estimates of the (US) National Research Council (1972). The three levels of L-lysine used to determine the rat's response to standard lysine were $0.75,1.5$ and $2.25 \mathrm{~g} / \mathrm{kg}$ (same batch of lysine as used for the pig assays). The protein concentrates were incorporated into the diets to supply the same three levels of total lysine as used to determine the standard lysine response. This was done at the expense of wheat starch. Additional maize oil was used with some protein concentrates to maintain the estimated digestible energy content of the diets.

For the rat assays, two female and two male albino rats, approximately $24-26 \mathrm{~d}$ old, were used per dose and were blocked on the basis of litter and sex (block size seven). The rats were individually caged in a room where the temperature and relative humidity were maintained at $21 \pm 1^{\circ}$ and $50 \pm 5 \%$ respectively. Lighting was provided for $12 \mathrm{~h}$ daily. Food was supplied in 'self-feeders'.

At the completion of a $14 \mathrm{~d}$ test, the rats were weighed, killed with chloroform and the alimentary tract, heart and lungs removed. The weight of the eviscerated carcass was recorded. Performance was assessed in terms of weight gain, FCE (g gain/g food eaten), carcass gain ( $g$ eviscerated carcass weight $-g$ initial live weight $\times 0.79$ ) and FCE on a carcass 
Table 4. Expt 2.* Dressing proportion, carcass gain and food conversion efficiency (FCE) on a carcass basis of pigs during the 20-45 $\mathrm{kg}$ growth phase when fed on the diets for a slope-ratio assay for lysine

\begin{tabular}{|c|c|c|c|c|c|c|}
\hline \multirow[b]{2}{*}{$\begin{array}{l}\text { Lysine dose } \\
\text { level }(\mathrm{g} / \mathrm{kg})\end{array}$} & \multicolumn{6}{|c|}{ Form of lysine addition } \\
\hline & $\begin{array}{l}\text { Free } \\
\text { lysine }\end{array}$ & $\begin{array}{c}\text { Linseed } \\
\text { meal }\end{array}$ & $\begin{array}{l}\text { Lupin-seed } \\
\text { meal }\end{array}$ & $\begin{array}{l}\text { Rapeseed } \\
\text { meal }\end{array}$ & $\begin{array}{l}\text { Sunflower } \\
\text { meal }\end{array}$ & $\begin{array}{c}\text { Sunflower } \\
\text { meal }\end{array}$ \\
\hline \multicolumn{7}{|c|}{ Dressing proportiont } \\
\hline 0 & 0.754 & - & - & - & - & - \\
\hline 0.5 & 0.752 & 0.732 & 0.746 & 0.746 & 0.730 & 0.742 \\
\hline $1 \cdot 0$ & 0.744 & 0.722 & 0.735 & 0.740 & 0.748 & 0.724 \\
\hline $1 \cdot 5$ & 0.750 & 0.712 & 0.731 & 0.745 & 0.743 & 0.724 \\
\hline $2 \cdot 0$ & 0.755 & 0.717 & 0.725 & 0.735 & 0.720 & 0.723 \\
\hline $2 \cdot 5$ & 0.749 & 0.697 & $0 \cdot 724$ & $0 \cdot 727$ & 0.728 & 0.726 \\
\hline $3 \cdot 0$ & 0.759 & - & - & - & - & - \\
\hline \multicolumn{7}{|c|}{ SEM 0.008} \\
\hline \multicolumn{7}{|c|}{ Carcass gain $(g / d) \ddagger$} \\
\hline 0 & 386 & - & - & - & - & - \\
\hline 0.5 & 394 & 391 & 391 & 384 & 392 & 381 \\
\hline $1 \cdot 0$ & 406 & 366 & 405 & 415 & 426 & 410 \\
\hline $1 \cdot 5$ & 433 & 383 & 426 & 425 & 424 & 402 \\
\hline $2 \cdot 0$ & 455 & 378 & 440 & 430 & 418 & 414 \\
\hline $2 \cdot 5$ & 453 & 347 & 444 & 426 & 443 & 442 \\
\hline 3.0 & 490 & - & 一 & - & - & - \\
\hline \multicolumn{7}{|c|}{ SEM 14} \\
\hline \multicolumn{7}{|c|}{ FCE (carcass basis) $\|$} \\
\hline 0 & $0 \cdot 290$ & 一 & - & - & 一 & - \\
\hline 0.5 & 0.296 & 0.293 & 0.291 & $0 \cdot 288$ & 0.291 & 0.284 \\
\hline $1 \cdot 0$ & $0 \cdot 308$ & 0.284 & 0.304 & $0 \cdot 308$ & 0.318 & 0.305 \\
\hline 1.5 & 0.325 & 0.284 & 0.318 & 0.316 & 0.315 & 0.301 \\
\hline $2 \cdot 0$ & $0 \cdot 337$ & $0 \cdot 285$ & 0.324 & $0-322$ & 0.308 & 0.308 \\
\hline $2 \cdot 5$ & 0.333 & 0.263 & 0.325 & $0 \cdot 321$ & 0.326 & 0.325 \\
\hline $3 \cdot 0$ & $0 \cdot 367$ & - & - & - & - & - \\
\hline \multicolumn{7}{|c|}{ SEM 0.008} \\
\hline
\end{tabular}

* For details, see p. 403.

$\dagger$ Hot carcass weight as a proportion of live weight before slaughter.

$\$$ Hot carcass weight - initial live weight $\times 0.69 \div$ period (d) on experiment.

II Hot carcass weight - initial live weight $\times 0.69 \div$ food intake.

basis ( $\mathrm{g}$ eviscerated carcass weight $-\mathrm{g}$ initial live weight $\times 0.79 \div \mathrm{g}$ food eaten). The factor of 0.79 for estimated eviscerated carcass weight was previously determined with eight rats (four male and four female) of similar live weight and age of those used for the assays.

The results were analysed by the slope-ratio technique of Finney (1964) for single assays. The mean availabilities and standard deviations were calculated.

No assays were conducted with the rapeseed meals as in earlier experiments the rats had refused to eat sufficient food to support adequate growth.

\section{Chemical analyses}

The techniques used were as reported by Batterham et al. (1979).

\section{RESULTS}

Performance results for the pigs in Expt 1 are presented in Table 2 and Expt 2 in Tables 3 and 4 . In both experiments the lean content of the hams increased slightly as the levels of dietary lysine increased and there were no significant differences between the slopes for 
Table 5. Availability of lysine (proportion of total) in the protein concentrates as assessed with pigs using daily live-weight gain, food conversion efficiency $(F C E)$, daily carcass gain and FCE on a carcass basis as the criteria for availability

(Mean values and standard deviations)

\begin{tabular}{|c|c|c|c|c|c|c|c|c|c|}
\hline \multirow[b]{2}{*}{ Expt no. } & \multirow[b]{2}{*}{ Protein concentrate } & \multicolumn{2}{|c|}{$\begin{array}{l}\text { Daily live-wt } \\
\text { gain }\end{array}$} & \multicolumn{2}{|c|}{ FCE* } & \multicolumn{2}{|c|}{$\begin{array}{l}\text { Daily carcass } \\
\text { gain } \dagger\end{array}$} & \multicolumn{2}{|c|}{$\begin{array}{c}\text { FCE } \ddagger \\
\text { (carcass basis) }\end{array}$} \\
\hline & & Mean & SD & Mean & SD & Mean & SD & Mean & SD \\
\hline \multirow[t]{2}{*}{1} & Rapeseed meal no. 1 & 1.05 & $0 \cdot 10$ & 1.09 & 0.07 & 0.96 & 0.11 & 0.97 & 0.08 \\
\hline & Sunflower meal no. 1 & 0.71 & 0.09 & 0.71 & 0.06 & 0.63 & $0 \cdot 10$ & 0.59 & 0.07 \\
\hline \multirow[t]{5}{*}{2} & Linseed meal & 0.29 & $0 \cdot 12$ & 0.35 & $0 \cdot 10$ & $-0 \cdot 21$ & $0 \cdot 16$ & -0.23 & 0.13 \\
\hline & Lupin-seed meal & $1 \cdot 22$ & $0 \cdot 18$ & $1 \cdot 16$ & 0.17 & 0.81 & 0.12 & 0.74 & 0.11 \\
\hline & Rapeseed meal no. 2 & 0.99 & 0.18 & 0.99 & $0 \cdot 17$ & 0.78 & $0 \cdot 14$ & 0.77 & 0.14 \\
\hline & Sunflower meal no. 2 & 1.07 & 0.16 & 0.99 & 0.14 & 0.74 & 0.11 & 0.66 & $0 \cdot 10$ \\
\hline & Sunflower meal no. 3 & 1.00 & $0 \cdot 16$ & 0.96 & 0.14 & 0.60 & 0.11 & 0.54 & $0 \cdot 10$ \\
\hline
\end{tabular}

* Live-weight gain $(\mathbf{k g}) \div$ food intake $(\mathbf{k g})$.

$\dagger$ Hot carcass weight -initial live weight $\times 0.69 \div$ period (d) on experiment.

I Hot carcass weight - initial live weight $\times 0.69 \div$ food intake.

Table 6. Availability of lysine (proportion of total) in the protein concentrates as assessed with rats using live-weight gain, food conversion efficiency (FCE), carcass gain and FCE on a carcass basis as the criteria for availability

(Mean values and standard deviations)

\begin{tabular}{|c|c|c|c|c|c|c|c|c|}
\hline \multirow[b]{2}{*}{ Protein concentrate } & \multicolumn{2}{|c|}{ Live-wt gain } & \multicolumn{2}{|c|}{$\mathrm{FCE}^{*}$} & \multicolumn{2}{|c|}{ Carcass gain $\dagger$} & \multicolumn{2}{|c|}{$\begin{array}{c}\text { FCE } \ddagger \\
\text { (carcass basis) }\end{array}$} \\
\hline & Mean & SD & Mean & SD & Mean & SD & Mean & SD \\
\hline Sunflower meal no. 1\| & 0.43 & 0.09 & 0.64 & 0.06 & - & - & - & - \\
\hline Linseed meal & 0.42 & $0 \cdot 10$ & -8 & - & 0.32 & 0.10 & 0.82 & 0.14 \\
\hline Lupin-seed meal & $\S$ & - & 0.97 & 0.17 & 0.59 & 0.08 & 0.86 & 0.12 \\
\hline Sunflower meal no. 2 & 0.49 & 0.12 & 0.72 & 0.11 & 0.48 & $0 \cdot 12$ & 0.68 & $0 \cdot 10$ \\
\hline Sunflower meal no. 3 & 0.50 & 0.09 & 0.59 & 0.07 & 0.43 & 0.06 & 0.49 & 0.08 \\
\hline
\end{tabular}

* Live-weight gain $\div$ food intake.

$\dagger$ Hot eviscerated weight - initial live weight $\times 0.79$.

$\ddagger$ Hot eviscerated weight - initial live weight $\times 0.79 \div$ food intake.

II From Batterham et al. (1978); carcass values not recorded.

$\S$ Slope-ratio values not calculated as curvature significant $(P<0.05)$ in linseed meal and intersection significant $(P<0.01)$ in lupin-seed meal.

each protein concentrate and the standard lysine responses. The level of inclusion of protein concentrates also depressed dressing proportion which was significantly lower than the standard lysine diets for sunflower meal $(P<0.05)$ in Expt 1 and linseed meal $(P<0.01)$ and lupin-seed meal $(P<0.05)$ in Expt 2.

In Expt 1, the availability of lysine in rapeseed meal was higher than that of sunflower meal (Table 5). Availability estimates were slightly lower on a carcass compared to live-weight basis, but there were only small and inconsistent effects of including food intake in the criterion of response.

In Expt 2, lysine availability of linseed meal was very low on a live-weight basis, and negative on a carcass basis. This meal was excluded from the analysis and the estimates 
Table 7. Availability of lysine (proportion of total) in the seven protein concentrates as assessed by the chemical Silcock assay, the direct fuoro-dinitrobenzene (FDNB) assay and by the slope-ratio assay with pigs and rats using food conversion efficiency on a carcass basis as the criterion for availability

\begin{tabular}{lcccc}
\hline \hline Protein concentrate & Silcock assay & $\begin{array}{c}\text { Direct FDNB } \\
\text { assay }\end{array}$ & Pigs & Rats \\
\hline Linseed meal & 0.93 & 0.71 & -0.23 & 0.82 \\
Lupin-seed meal & 0.98 & 0.68 & 0.74 & 0.86 \\
Rapeseed meal no. 1 & 0.93 & 0.71 & 0.97 & $-*$ \\
Rapeseed meal no. 2 & 0.83 & 0.71 & 0.77 & - \\
Sunflower meal no. 1 & 0.92 & 0.46 & 0.59 & $0.64 \dagger$ \\
Sunflower meal no. 2 & 0.87 & 0.71 & 0.66 & 0.68 \\
Sunflower meal no. 3 & 0.94 & 0.88 & 0.54 & 0.49 \\
\hline \hline
\end{tabular}

- Not determined.

$\dagger$ Potency estimate is based on food conversion efficiency on a live-weight basis.

for the remaining four meals re-analysed. Performance values for the four pigs fed on the top level of rapeseed meal $(2.5 \mathrm{~g} / \mathrm{kg}$ lysine $)$ were inconsistent, with two pigs rejecting considerable quantities of feed. Performance results for this level of rapeseed meal were also deleted from the analyses. All meals had high lysine availabilities on a live-weight basis, but considerably lower on a carcass basis. Estimates based on FCE were in most instances slightly lower than those based on a gain basis.

Rat slope-ratio estimates for lysine were lower on a carcass compared to live-weight basis and higher when food intake was included in the criterion of response (Table 6). When FCE on a carcass basis was the criterion of response, there was general agreement between the rat and pig availability estimates.

The Silcock available-lysine values ranged from 0.98 for lupin-seed meal to 0.83 for rapeseed meal no. 2 (Table 7). Values for the direct FDNB procedure were lower than the Silcock values and ranged from 0.88 for sunflower meal no. 3 to 0.46 for sunflower meal no. 1. For comparative purposes, the slope-ratio values for pigs and rats are also presented in Table 7. There was little relationship between the chemical estimates and the slope-ratio assay values.

\section{DISCUSSION}

The results of the slope-ratio assay with pigs indicate that there are considerable differences in the availability of lysine in vegetable protein concentrates. As in Batterham et al. (1979) availability estimates based on a carcass basis were lower than those based on a live-weight basis and with most meals the differences were substantial. The lysine content in many vegetable protein concentrates is relatively low and in order for the meal to contribute $2.5 \mathrm{~g}$ total lysine $/ \mathrm{kg}$ to the diet, levels of over $200 \mathrm{~g}$ vegetable protein concentrate $/ \mathrm{kg}$ may be required. Such levels may contribute approximately $50 \mathrm{~g}$ crude fibre $/ \mathrm{kg}$ to the diet, which can have a marked effect on intestinal contents and hence dressing proportion. The effect would be particularly marked under the experimental procedure adopted as the interval between last feed and time of slaughter was only 3-5 h. It is surprising that the differences in availability estimates between carcass and live-weight values were not as great in Expt 1 as they were in Expt 2. As in Batterham et al. (1979) there were little differences in availability estimates on an FCE compared to a gain basis, and little would be expected, as the pigs were fed on a limited feeding regimen.

With rats, availability estimates were also lower on a carcass basis but were considerably 
higher when food intake was included in the criterion of response. FCE on a carcass basis appears the most appropriate of the four production criteria assessed, as it would be the least affected by depressed intake due to fibre content in the diet, differences in dietary protein quality and differences in intestinal contents. Availability estimates based on this criterion were in agreement with those in pigs, except for linseed meal, which was considerably higher with rats.

The negative value for available lysine in linseed meal indicates the possible presence of a growth depressant either on or in the meal. There appears to be little information on the effects of linseed meal at high inclusion levels $(200 \mathrm{~g} / \mathrm{kg})$ in diets for pigs. If the raw seed is wetted it can develop prussic acid as a result of the action of an enzyme from linamarin, a compound present in the seed (Simmons, 1963). However, the enzyme is destroyed by heat so that prussic acid should not be a problem in properly processed meals. Linseed meal also contains an antipyridoxine factor for chickens (Liener, 1969) and if applicable to pigs this factor may have depressed growth performance. The growth response of pigs to increasing level of linseed meal was however, linear. It is unusual that a curvilinear effect did not result, thereby making the potency estimate statistically invalid. With rats, the inclusion of linseed meal in the diets depressed voluntary food intake. This had a marked effect on growth and this is reflected in the low slope-ratio estimates when gain was used as the criterion of response. The higher estimate based on FCE indicates that factor other than lysine availability were interfering with rat performance and the latter estimate appears more applicable than those based on gain.

The low estimates for available lysine in sunflower meal confirms the estimate of Batterham et al. (1978) and presumably reflects processing damage. Similar damage appears to occur with both expeller and 'prepress' solvent-extracted meal (nos. 2 and 3). It appears that the main effect of the solvent process was to remove more of the residual oil that remains from an expeller process rather than to reduce the level of damage by heat. The two samples of rapeseed meal were supplied by the one firm and the variation in availability values may reflect variation in processing conditions within the one plant. Variable protein quality in rapeseed meal has been reported by Taverner \& Rayner (1975) who found an expellerprocessed rapeseed meal superior to a 'prepress' solvent-extracted meal.

The Silcock assay values confirm the observations of Batterham et al. $(1978,1979)$ that the technique does not detect the availability of lysine in protein concentrates for pigs or rats, as assessed by the slope-ratio assay. The Silcock assay is a very precise technique. In our laboratories we have observed a range of approximately $0 \cdot 10$ in estimates for lysine availability for different samples of the one type of commercially-processed protein concentrate (i.e. $0.93-0.83$ for rapeseed meal). In the present experiments we compared rapeseed meals and sunflower meals with high and low Silcock values to determine if these differences could be used to rank these meals on a relative lysine basis. With rapeseed meal, the order of the Silcock values corresponds to the order of the lysine availabilities for pigs. This supports the results of Taverner \& Rayner (1975). For sunflower meal, there was little difference in the slope-ratio values for pigs and rats and the latter differences may reflect variability associated with that technique. Further research is needed to determine whether the range in Silcock values with the one type of meal can be used to rank lysine availabilities for pigs and rats.

Available lysine estimates by the direct-FDNB procedure showed a greater range in values and were lower than the Silcock values. The values showed little relationship to the slope-ratio estimates for pigs and rats. The greater range in FDNB values may reflect the instability of dinitrophenyl-lysine in the presence of carbohydrates in vegetable protein concentrates. This interference is avoided with the Silcock assay. The low available lysine content in the vegetable proteins appears to reflect heat damage not associated with the free $\epsilon$-amino group 
of lysine. Such mechanisms could involve reactions among other amino acid linkages or absorption of lysine in a form unsuitable for utilization. If it were the former, then the availability of other essential amino acids would also be affected. It is necessary to elucidate the cause or causes of the low availability of lysine in vegetable protein concentrates in order that techniques for its assessment can be developed.

The authors thank Messrs N. R. Thompson, A. W. Davis, H. M. Essery and E. R. Layton for management of the pigs and skilled technical assistance. This work was supported by financial grants from the Australian Pig Industry Research Committee.

\section{REFERENCES}

Batterham, E. S., Murison, R. D. \& Lewis, C. E. (1978). Bri. J. Nutr. 40, 23.

Batterham, E. S., Murison, R. D. \& Lewis, C. E. (1979). Br. J. Nutr. 41, 383.

Batterham, E. S. \& O'Neill, G. H. (1978). Br. J. Nutr. 39, 265.

Carpenter, K. J. (1960). Biochem. J. 77, 604.

Finney, D. J. (1964). Statistical Method in Biological Assay, 2nd ed. London: Griffin.

Lewis, D. \& Cole, D. J. A. (1976). Proc. Nutr. Soc. 35, 87.

Liener, I. E. (1969). Toxic Constituents of Plant Foodstuffs. New York: Academic Press.

National Research Council (1972). Nutrient Requirements of Laboratory Animals, 2nd ed. Washington DC: National Academy of Sciences.

Roach, A. G., Sanderson, P. \& Williams, D. R. (1967). J. Sci. Fd Agric. 18, 274.

Simmons, N. O. (1963). Feed Milling and Associated Subjects, 2nd ed. London: Leonard Hill (Books) Ltd.

Taverner, M. R. \& Rayner, C. J. (1975). Aust. J. exp. Agric. Anim. Husb. 15, 626. 